'THE PEOPLE SHALL GOVERN'

\title{
THE ROLE OF THE CHURCH IN THE DEVELOPMENT OF PARTICIPATORY DEMOCRACY IN SOUTH AFRICA
}

\author{
Simanga R Kumalo \\ School of Theology and Religion \\ University of Kwazulu-Natal
}

\begin{abstract}
This research focuses on the role that needs to be played by the church in the development of democracy in a democratic South Africa. It argues that since the church played an important role in the struggle against apartheid and during the transition to the formation of a democratic government, it has to continue being involved in influencing the political life of the country. However, the first decade of democracy has seen the church retreating to denominational conclaves leaving a vacuum in the political arena. This is blamed to the tight control and centralization of government which makes it difficult for citizens and civil society organizations, such as the church, to penetrate and participate. Then it calls for the church to consider active participation in the development of democracy by suggesting ways of political engagement for the church in South Africa.
\end{abstract}

Keywords: Religion, Governance, Politics, Church, Neutral-Religious State

\section{Introduction}

Robust participatory-democracy and good governance are some of the most important components of development in any society. This paper seeks to encourage the church to participate in the development of a culture of democracy in South Africa. It will demonstrate that democracy is still at an infancy stage in South Africa and needs important sectors, such as the church, to make use of available spaces and create some to contribute to its maturity. This research seeks to answer the question, "How can the church contribute to the development and consolidation of a democratic political culture in a post-apartheid South Africa?" The key term is democracy, which in this essay is understood as "a system of governance where values essential for a way of life are characterized by an equality of opportunities for all, respect for the dignity and rights of everyone and freedom from suppression" (Cloete, 1993:186). Democracy is one historical system through which the quest for good governance has been expressed. By the term 'church' in this paper we are referring both to formal denominations and to the ecumenical movement representing these different denominations. The research comprises four main sections. First, we introduce the research. Second, we examine the historical development of church-state relations in South Africa. Third, we reflect on the shifting of paradigms of church state relations during the transition from an apartheid government to a democracy. Fourth, we identify factors inhibiting the participation of the church and propose practical strategies that need to be embarked upon if the church is to make a contribution. Fifth, we draw the research to a conclusion. The comprehensive scope of this topic requires that we also engage in dialogue with other disciplines such as politics, development studies, social sciences and life sciences. 


\section{The Historical Development of Church-state Relations in South Africa}

Currently church-state relations in South Africa are described by the term "Critical Solidarity" which means "that the church supports those government initiatives that promote justice, peace and democracy whilst continuing to protest against unjust policies and protecting the interest of the poor and minority groups" (Villa- Vicencio, 1992: 27). It is important for us to trace the stages through which church-state relations have developed in the history of South Africa in order to lay a foundation for our discussion. Through the evolution of the South African society, church-state relations have moved through five 'generations'. ${ }^{1}$ From 1652-1800, the period of the arrival of the Dutch settlers mainly from the Dutch Reformed Church, the relationship was characterised by an uncritical acceptance of the state by the church. The church and the state were one and the same thing (De Gruchy, 2004: 1). From 1801-1911, after the British took control of the Cape and established the Natal Colony, and the Boer Tekkers established their own independent republics (Transvaal and Oranje Vrystaat), church-state relations were characterised by critical acceptance. This was a period when missionaries, especially those from Englishspeaking churches such as Anglican, Methodist, Presbyterian and Congregational, proliferated the Cape and a small number of these missionaries were critical of both the Colonial government and sometimes the church in the way they treated African people. They were also critical of the Boer republics and their racist laws (Elphick, \& Davenport, 1997:51). ${ }^{2}$ Linked to this was the growth of educated indigenous African Christians sometimes referred to as mission educated elites who were starting to play a pivotal role in both the church and wider society calling for the recognition of black people's rights. ${ }^{3}$

Following the Union of South Africa (1910), church-state-relations from 1912-1960 were demonstrated by 'critical opposition' because at this time some sections of the European churches and the majority of black churches began to resist the government's policies. These policies intentionally excluded black people from decision-making structures of the country. ${ }^{4}$ The opposition was fuelled by the emergence of progressive movements such as the South African Native National Congress (SANNC) in 1912 which was the predecessor of the African National Congress (ANC). Critical opposition intensified in the 1930s when the Council of Churches of South Africa (CCSA) organized conferences to conscientize churches about the unjust policies of government that needed to be resisted. This was continued until 1949 when the Nationalist government showed determination to implement its policies of separate development, popularly known as apartheid (De Gruchy, 2004:264). From 1961-1990, the church-state relations became a matter of intensive resistance. However, this refers to churches that resisted the state not the Dutch Reformed Church which chose not to resist the apartheid government but rather supported it by giving foundational theological motivations for its rationale. The period of resistance led to the holding of the Cottesloe Consultation, the work of the Rev Beyers Naude and the Christian Institute, the growth of the initiatives such as the Black Consciousness Movement, (BCM), Black Theology, The Message of the People of South

\footnotetext{
See also Kumalo, S Paying the Price for Democracy in De, Gruchy, S Kopman, N \& S Stribos (ed.) From Our side (Amsterdam: Rosenberg Publishers, 2008), 171.

Such missionaries included people like John Phillip, George Schmidt, and Van der Kemp, and Barnabas Shaw.

These included leaders such as Tiyo Soga, Nehemiah Tile, John Tengo Jabavu, and Mangena Mokone. It was during this period that black missionary-educated leaders such, Pixley-ka Isaka Seme, ZK Mathews, John Dube, Charlotte Maxeke, Walter Rabusana, and ZR Mahabane, formed the African National Congress, mobilized black people against Colonial government, and organized marches and prayer rallies to oppose it.
} 
Africa, the banning of the ANC and the Pan Africanist Congress (PAC) and the Programme to Combat Racism (PCM).

From 1991-1994 the activist-church under the leadership of the SACC played a mediatory role, by standing between the apartheid government and liberation organizations to facilitate negotiations and ultimately the elections in 1994. After 1994 South Africa was declared a neutral-religious state which recognizes all faiths and permits the observances of religious practices in its institutions without being biased in favour of any particular religion. ${ }^{5}$ In this period the church defined its relationship with the state as one of critical solidarity. This mode of engagement was formalized in 1995 at an SACC conference in Vanderbijlpark.

The foundational motivation for the church's involvement in the consolidation of democracy using the critical solidarity approach is based on the quest for a system that approximates the principle of governance in God's household oikos ${ }^{6}$ where justice, peace, dignity, and equality are upheld (Ephesians 2:19). The mission of the church is to introduce the reign of God on earth that brings about shalom, with all its attributes. It is the people's quest for peace in its fullness that compels the church to be involved in matters of democracy and good governance. The church has an important role to play by empowering people to participate in processes leading to democracy and enabling them to protect their and other people's intrinsic rights in society as they live their lives. According to the latest survey of 2005, it has been observed that more than $79 \%$ of South Africans profess to be Christians, (Hendricks and Erasmus, JTSA, 121, 96, 2005) which means that the church in South Africa reaches all sectors of society and has the potential to mobilize more people than most social movements in the country.

\section{The Shifting of Paradigms: From Resistance to Assistance}

The need to discuss the church's role in SA comes as a result of the changes that took place in the political life of the country in 1990. When the National Party government realized that they were not winning the war against the resistance to apartheid, they embarked on a dramatic change of direction. In August 1989, PW Botha was forced to resign, and FW de Klerk took over as State President (De Klerk, 1998:149). Widely regarded as a verligte (enlightened one) within the Afrikaans community, De Klerk was a member of the Gereformeerde Kerk (Dopperkerk) and a son of a former National Party leader (De Gruchy, 2004:206). In February 1990 De Klerk shook the country by announcing the imminent release of Nelson Mandela and other political prisoners. The legalization of the African National Congress (ANC), the Pan African Congress (PAC) and other political organizations followed this event. Although the activist-church appreciated the changes, they were too dramatic for many Christians because they were caught unprepared. For a long time some parts of the church had been the site of the struggle against the state and its apartheid policies. John Allen observed "Church pulpits and assemblies provided an unrivaled array of platforms at a time when few others were available in the black community" (Allen, 2006:233).

The progressive churches were faced with the challenges of finding a way forward and an appropriate theology for ministry as the new socio-political and economic conditions

\footnotetext{
Unlike France and the US which adopted a secular-state approach, which forbids the observation of religious practices in their institutions, in South Africa the constitution allows the observation of religious practices in public institutions such as schools, hospitals and even national ceremonies such as inauguration of the president and national rallies.

6 De Gruchy, S Oikos Journey (Durban: Diakonia Council of Churches, 2005).
} 
were taking shape. A number of church leaders became involved as mediators between the negotiating parties. They also took part in peacekeeping efforts in the townships that were engulfed by political violence at the time (De Gruchy, 2004:206). Some theologians called on the church to change its involvement strategies with the government from a prophetic 'no' to a 'yes,' and from 'resistance' to 'assistance (De Gruchy, 2004: 26). Charles VillaVicencio noted that:

The challenge now facing the church is different. The complex options for a new South Africa require more than resistance. The church is obliged to begin the difficult task of saying 'Yes' to the unfolding process of what could culminate in a democratic, just and kinder order (1992:27).

After the release of political prisoners and the unbanning of political organizations the next challenge was to embark on negotiations. The ANC and its alliance partners had the prerogative of leading the negotiation process. The churches were fully involved in this process; church leaders opened the negotiation process with prayers and organized a number of prayer rallies throughout the country. At the same time as the negotiations were going on there was 'black on black violence', fuelled by a number of key points of disagreement between the ANC and another black-led organization, the Inkatha Freedom Party (Temkin 2004:140). As a response to the conflict church leaders such as Archbishop Emeritus Desmond Tutu, Bishop Stanley Mogoba, Bishop Mvume Dandala, Bishop Peter Storey and many others became involved in intervention strategies for peace.

In the midst of these activities of facilitating reconciliation and pastoral accompaniment of the negotiation process the church recognized the need for an ecumenical conference to discuss strategies for its ministry in the new South Africa. In November 1990 a conference was convened by the SACC in Rustenburg, a small town not far from Johannesburg bringing together 230 participants representing 97 denominations and 40 church associations, as well as a number of ecumenical agencies such as Diakonia and the Institute for Contextual Theology and others (Chikane \& Alberts 1991:140). The main aim of the conference was to foster reconciliation in South Africa and to forge a way forward in the ministry of the church after apartheid (Chikane \& Alberts, 1991:10). A further key aim, as noted by Frank Chikane, was "an attempt to work towards a united Christian witness in a changing South Africa" (Chikane \& Alberts, 1991:10). The outcome of the Rustenburg Conference was a document whose aim was to form the basis for the process of reconciliation and healing for South Africa. ${ }^{7}$ Included amongst the points agreed upon in the Conference document were:

- The unequivocal rejection of apartheid as a sin.

- The recognition that the conference had met at a critical time of transition, which held out a promise of reconciliation and that Christians were called to be a "sign of hope" from God, and to share a vision of a new country.

- The need for repentance and practical restitution for God's forgiveness and for justice as a preparatory step of reconciliation.

On 27 April 1994 and the birth of a new government in South Africa the church continued to contribute by training over a thousand clergy and Christian lay-leaders to work as election officials and monitors. As already noted above once the democratic government was inaugurated it declared the country a neutral-religious state. Looking back at the role that had

The Rustenburg conference involved different church associations, ecumenical organizations, church leaders and academics. 
been played by the church from the struggle against apartheid to the transition to democracy the then President Nelson Mandela applauded the churches by saying that "This you did not as outsiders to the cause of democracy, but as part of society and eminent prophets of the teachings of your faith" (Asmal, 2003: 326). This demonstrates to us the important role played by the churches in the political life of the country, thus reminding us of the important role that the church can play in a democratic society. Therefore, it is not surprising that a 2006 social-survey by a national research organization showed that the church is the most trusted institution in South Africa for 81\% of the population (Pillay, 2006:32).

However, soon after the new government was inaugurated in a ceremony that was opened and blessed by religious leaders from the diverse faiths of SA, church leaders began to retreat from the public platforms to denominational enclaves. Some of the leaders of the church who had left the struggle joined government whilst others went to work for NGOs and the private sector. ${ }^{8}$ The shift from public ministry to denominational focus was demonstrated by two significant leaders when they also announced their own departure from politics. These were bishops Desmond Tutu and Manas Buthelezi. After introducing Nelson Mandela as the newly elected President of a democratic South Africa on the stairs of the Union Building in April 1994, Bishop Desmond Tutu exclaimed, "Now I am going back to the church to do the real business of the church and leave politics to those well qualified to do it" (Challenge Magazine, 22 June, 1994). Coincidentally when Bishop Manas Buthelezi, a proponent of black theology and former president of the SACC, spoke in his farewell function in 1997 at the Jabulani Amphitheatre in Soweto he said, "Now I am going to serve the real church" (Challenge Magazine, 13 October, 1998). The churches that retreated to denominational enclaves were mostly mainline churches, whilst paradoxically the charismatic groups moved into the center as they opposed government's policies on moral issues such as abortion and same-sex relationships. Although there is no empirical evidence that the statements by the two theologians of the struggle led to the church's withdrawal from the public sphere, they do however give us a "window" on the dominant thinking by church leaders on church -state relations in a democratic South Africa.

\section{Factors inhibiting Participation of the Church}

The question that remains to be answered is what are the mitigating factors for the lack of participation of the church in the political life of the country. Through the Religion and Governance Programme we have been able to identify seven key factors that inhibit the church from participating in political issues, and thus in contributing to processes around democracy and good governance.

\section{A Parliamentary Democracy}

One of the key criticisms leveled against the South African government has been the centralization of power around the presidency. There is a feeling that government is tightly controlled by the president so that it is difficult for other groups, whether civil society, opposition parties or faith communities, to engage with it or participate in it. The first person to raise these concerns was Archbishop Tutu when he delivered the Nelson Mandela lecture in 2005 at the University of the Witwatersrand in Johannesburg. The second observation about the lack of a robust democracy as a result of too much centralization of

8 Some of those who joined government as important leaders of departments and commissions were people such as Frank Chikane (Director General in the office of the President), Itumeleng Mosala, Makhenkesi Stofile, Simangaliso Mkhatshwa etc. 
power came from one of the key members of the Tripartite Alliance (which includes the ruling party), the South African Communist Party (SACP) who argued:

It (the presidential centre) has sought to build a strong centre within the state, in which the leading cadre is made up of a new political elite (state managers and technocraticallyinclined ministers) and (often overlapping with them) a new generation of black private sector BEE managers/capitalists (Bua Komanisi, 1May 2006). ${ }^{9}$

The reason for the resentment of the centralization of power was that it goes against one of the key principles of the Freedom Charter which states "The People Shall Govern" (Polley, 1988:25). ${ }^{10}$ The question that needs to be asked today is, are the people really governing? Political theorist Xolelwa Mangcu argues that "the people are not governing but instead they just follow the elected leaders." He argues, "Many of the former activists in South Africa have found that they have to go along" (Calland \& Graham, 2005:72). When listening to the majority of South Africans, it is clear that they hoped for a decentralized government built on the basic foundations of direct democracy. However, that is not what they are experiencing. Mangcu blames the centralization of government on the negotiation process, its approach and pacts. He said:

While the political transition itself was the result of mass mobilization in the townships and villages of this country, the negotiations for democracy were at times, a secretive affair, the outcomes of which hinged on the bargaining skills of the leaders of the various political parties, mainly the ANC and the National Party (2005:74).

The same observations are made by Richard van der Ross in his book African Renaissance and Democracy where he asserts that:

Even today, most South Africans, of whatever colour, do not consider that they can do much, if anything, about influencing the law, let alone change it. They go to the polls once in five years, cast their vote for a party, and leave the rest to the politicians. If things go wrong, this is blamed on government, but they, the citizens, feel they can do nothing about it until the next election, especially as, under the system of proportional representation, they have no immediate contact with or recourse to a Member of Parliament to act as a local sounding-board for their complaints or opinion (2004:24).

As a result democracy in South Africa has been labeled as a 'Parliamentary Democracy' where elected representatives run the government on behalf of the masses (Bua Komanisi, 24 May 2006) which is not appropriate for democracy. Citizens wait for delivery of services as promised and so the government is seen as a delivery-mechanism not a system of participation in the governance of the country. Civil society groups are finding it very difficult to influence government as required by democracy which is the government of the people. In the words of Peter Vale it is no longer a "living democracy" (Calland \& Graham 2005:13). K. Fayemi points to the problem with this when he notes; "when we the people withdraw our trust in leaders or discountenance politicians, we make our democratic institutions less effective and risk making ourselves ungovernable". Fayemi goes on to argue that:

Real leadership ought to involve motivating people to solve problems within their own communities, rather than reinforcing the overlords of the state over its citizens, and to

9 BEE refers to Black Economic Empowerment, a strategy aimed at balancing the economic inequalities by offering black people opportunities to own businesses.

10 The Freedom Charter is the founding document which was accepted by a broad-based conference of the people in 1955 in Kliptown Johannesburg as a document through which they would fight for freedom and democracy. 
build and strengthen political institutions that can mediate between individual and group interests (2006:56).

The church (like other civil society groups) is confronted with the question of how to penetrate, analyze and influence this impenetrable and quarantined form of government with its principle of participatory governance, where there are open-spaces for citizens to participate. This has been seen as one reason for the lack of participation.

\section{No Socio-Ecclesial Analysis, no Voice}

Churches have relative autonomy from the state as well as vice versa? Penetrating any centralized system of government requires churches to be intentional. To move towards engaging government, requires a rigorous process of analysis so that the reasons, issues and terms of cooperation, or resistance can be seen clearly. This requires the church to do socioecclesial analysis. Analysis enables the church to see the issues that need to be contested or affirmed much more clearly from an informed position. This was confirmed by Itumeleng Mosala when speaking in the RGP convention in 2005, he said "no analysis, no voice" (Report of Convention, 2005:12). This means that the ability of the church to engage government lies in the amount of work it is going to do in socio-ecclesial analysis. Through the RGP reflections, research and socio-ecclesial analysis done by ecumenical structures have continued where churches look at specific issues in the post-apartheid era. These issues include human rights issues, the rule of law, basic human rights, accountability, and transparency, delivery of basic services, and democracy in private and public space such as family units, church, government, and business.

\section{Lack of a Contextual Theology of Democracy}

During the struggle against apartheid there was an abundance of liberation theologies and theologians that helped the church with theological frameworks when doing their socioeconomic and political-analysis work. Despite the fact that theology had inspired the church to fight apartheid it was still viewed with suspicion by politicians. Two reasons were given for this suspicion. First is that theology had been used to justify apartheid? Second, it had been used by the apartheid government to divert students from science disciplines to humanities so that they would remain subordinate to whites who were doing the difficult subjects such as science and business. As a result when black people took over the government they wanted to reverse this legacy. This led to a closure of theological faculties and a mass departure of theologians to other fields such as government and the private sector. Reacting to the marginalization of theology from political life Archbishop Tutu has argued for a theology that will propagate the church's involvement in politics:

If we say that religion cannot be concerned with politics, then we are really saying that there is a substantial part of human life in which God's writ does not run. Religion is not a form of escapism. Our God does not permit us to dwell in a kind of spiritual ghetto, insulated from the real life out there. Our God is not a God who sanctifies the status quo.

He is a God of surprises, uprooting the powerful and unjust to establish His Kingdom (in Sparks, 2006:295).

These are sinews of a theology of democracy that must be developed by the church, to guide its involvement in the changing political life of a democratic South Africa. For the past eleven years the church has been searching for a theology of democracy, but how can this be realized when it does not do any political theological reflection? Linked to the above was the discarding of theologies of liberation such as liberation theology, black theology, and African theology as redundant. It was common in South Africa to hear theologians of 
struggle saying, "The time of liberation theology is over, we no longer need black theology"; or "Now we are one, we no longer need African theology because it is no longer clear who is and who is not an African in South Africa". If you talk of black theology and African theology in South Africa today you can be accused of discrimination, or being seen as an angry black person who is still trapped in the theologies of the past. These theologies provided us with helpful theoretical frameworks that helped us to think critically. The discarding of these theologies without any proper replacement has left the church with very few resources as far as theological frameworks and tools are concerned. Only a few resources have been published in this area. These are John de Gruchy's Christianity and Democracy, Barney Pityana's Being the Church in South Africa Today (Johannesburg: SACC, 1995), Isabel Phiri's article on The Christian Nation and Democracy in Zambia (JRA, 33.42003 ) and Jesse Mugambi's From Liberation to Reconstruction (Nairobi, EAEP 1995).

The pastoral responsibilities of the church include accompanying the newly established democratic nation through a crucial process of confession, forgiveness, healing, reconciliation, transformation, and reconstruction (De Gruchy1995: 217). Through this the church can nurture a democratic culture. Good governance is possible and is "well exercised when it relies on local direction, knowledge and capacities." (Shearing \& Wood, 2005:106). The lack of participatory governance in the church is against the biblical understanding of governance in the household of God.

The facilitation of theology and democracy workshops and seminars creates a way for the church to draw from the theological traditions that emphasize the inherent right and ability to participate in policy and decision-making. True participation in governance in God's household means "not participation in general, but priority is put on participation of the oppressed and marginalized people who hitherto had been written off and pushed off to the periphery as mere pawns in the development arena"(Kobia, 2003:118). Understanding participation from this perspective means that we place greater significance on what is seen as peripheral, rather than what is seen as the center. It builds on liberation theology's conviction of God's preferential option for the poor and marginalized. In the process of doing a theology of democracy there is a need to pose particular questions that enable us to get to the heart of the issues. For example Miguez Bonino suggested that Christians ask the question, "How is God's rule of justice which is paradigmatically disclosed in Jesus Christ and destined to be the true future and the inescapable judgment of all political life - how is it mediated in the struggles of history?" (Bonino, 1983:11). A theology of democracy is based on the church's wider vision which is good governance, and which is measured by applying the principles in God's household such as equality, justice, equal distribution of resources, community, belonging, dignity for all, participation and dialogue etc. This theology is already present both in literature and in the praxis of Christians as they live out their faith. What is needed is the intention to reflect on it, so that it can be discovered, brought to life through discussions and ultimately has an influence on the people's daily lives.

\section{The Spirit of Comradeship}

Another reason for the lack of a critical involvement of the church in public issues is the common history that those in government share with church leaders. Many of the leaders in government have been involved in churches either as members, workers, or activists through faith-based organizations such as the SACC, Institute of Contextual Theology (ICT), and Diakonia etc. They know the current leaders of the church at personal level. 
These people marched, slept in prisons, and were tortured together and even protected one another in the face of the brutality of the security forces. Thus those who remained in the church find it difficult to criticize their comrades who are now in government. They still regard one another as comrades committed in the ideals of the liberation movement, forgetting that they have shifted their roles from that of activists to leaders of government and they need to be treated and understood as such. They still believe in their commitment to the well being of all people that those old comrades once cherished. Archbishop Tutu echoed these sentiments when he lamented his own naivety with regard to this issue:

I must confess that I have been quite naive. During the days of our struggle our people were magnificently altruistic. We had a noble cause and almost everyone involved was inspired by high and noble ideals. When you told even young people that they might be tear-gassed, hit with quirts or have vicious dogs set on them, that they might be detained and tortured and even killed, there was a spirit almost of bravado as they said: "So what? I don't care what happens to me as long as it advances the cause." My naivety was that I believed that these attitudes and exalted ideals would, come liberation, be automatically transferred to hold sway in the new dispensation. What a comprehensive let down - no sooner had we begun to walk the corridors of power than we seemed to want to make up for lost times. We succumbed to the same temptations as those others we had thought to be lesser mortals (Mail \& Guardian, 23 August 2006).

It was perhaps due to this 'naivety' that Tutu made the statements calling for the church to return to the real business of the church and leave politics to those better qualified for it. A number of church leaders have not yet come to realize this mistake, and still believe in the bone fides of the political leaders. They do not see the need to be vigilant, and they remain fatalistic. One Methodist bishop once related to this by saying "Simanga, it is very difficult to criticize your friends once they are in power; you sometimes wish somebody else can do it on your behalf." (Interview with Bishop Dlangalala, 14 June 2006).

Political accountability in modern democracies requires that the church and other elements of civil society serve as watchdogs that will raise their voices when there is something amiss in order to keep leaders accountable to their constituencies. The methods of protest are expressed through public criticism of the individuals, sometimes to the extent of demonizing the individuals, calling them names, and calling for their dismissal. Most black African cultures including the South African Zulu, Xhosa, Swazi, Venda, Sotho, Tswana etc are built on a "shame cultural norm". According to this, citizens do not criticize any person in public even if they are guilty, because this involves adding shame upon them, instead of edifying or rehabilitating them. If any person has done something wrong, especially if the person is a leader, it is expected that one will follow certain channels to call them to order and even punish them, without adding to their already destroyed moral integrity by demonizing them in public. This kind of thinking is also in line with how the guilty are dealt with in scripture, especially in the New Testament when doing a literal reading of texts such as the woman, caught in adultery (John 8:1-10), Zachaiaus (Luke), and the prostitute in the Pharisees' house (Luke 7:37-50).

Most church leaders struggle on a personal level to openly criticize political leaders because they are products of this cultural upbringing. Even though they may join a crowd in protest, when it comes to the personal level, they struggle with how to deal with the question of guilt in the face of the shame situation that some of their leaders face. As a result, they close themselves with their church issues instead of dealing with political issues that will require them to face leaders with public criticisms. Thus, the cultural background of most African bishops contributes to this problem. This challenge requires that we look at the fact that Western democracy as it is needs to be analyzed critically before it can be 
applied in an African context. There is a need to ask the question "how do we deal with those fundamental principles of democracy that are incompatible with African culture?" Linked to that is the observation that Western democracy has limitations that can be addressed by learning from some of the fundamental principles of African culture such as holism. Can the church claim neutrality and non-commitment when it comes to social issues? Theologically speaking, there is no basis for the church to stand aloof from public issues. It has to be recognized that the church is in the world, although it is not of the world (John 16:10-15). One of the fundamental principles of African culture is the interconnectedness and holistic nature of life. Life cannot be separated into what is sacred and secular or into what is political and religious (Setiloane, 1986:33). From this perspective, the church is an important stakeholder in the political processes in South Africa. However, the church has to maintain relative autonomy. Whilst being conscious of the role it has to play in the political sphere as a stakeholder, it must maintain its uniqueness and autonomy from the state.

There is also a need for the church to draw from cultural resources for good governance found in African worldviews such as the concept of umhlangano ${ }^{11}$ (a Zulu word for interactive forums) where issues are deliberated upon by all people, from diverse groups and stakeholders whilst they maintain their uniqueness until they reach consensus. This can be a helpful one in understanding the basis from which the church can engage the state.

\section{Education for Critical Solidarity}

As mentioned in the introduction, the key term is critical solidarity, which means that the church supports initiatives which promote justice, peace, and democracy while continuing to protest against unjust policies and protecting the interest of those vulnerable and minority groups. By nature the church is a community of solidarity, a people who care, support and stand in community with others. It needs to re-define itself from the understanding that it is an enemy of the state as it used to be during the struggle, but rather that it is an important critical and honest friend of the democratic state. This means that a new approach to church-state relations needs to be developed which moves away from the dominant models in which the church is either absorbed by the state or regards the state as an enemy and one where the church maintains an independent and critical stance from which it can engage government either with affirmations or criticism depending on the circumstances. This proposes a new approach from the old ones where the church was either a puppet of the state or an enemy. Tinyiko Maluleke phrases it as "We must move away from the two extreme models of church-state interaction: lapdog or cat and mouse" (Ecumenical Consultation Report, 23-26 March 2003).

The notion of 'critical solidarity' is built on the foundations of liberation theology and theologies of reconstruction, which continue the tradition of God's preferential option for the poor. It calls for obeying the laws of the country only if they are not contrary to the laws of God, (Acts 4:19, 5:29). It also calls for respecting those in authority (Romans 13:1-2), because they have been put there by God; this is especially so when it is a legitimate government. The churches also base their participation on the text that says, "The earth is of the Lord and all that is in it", (Psalm 24:1) thus bringing congruence between ecclesial and societal issues. This includes an embrace of the liberal constitution that declared the country a neutral-religious sate. Being a neutral-religious state means that "South Africans

11 The concept of umhlangano comes from the Zulu form of public meetings because of their consultative nature that can take days before a decision can be made so as to gather as much consensus as possible. 
are protected from both theocracy and atheism, meanwhile allowing religion to exist without any constitutional impediments" (Villa-Vicencio, 1992:264). For the model of critical solidarity to be understood by the whole church and to be put into practice from the local government, to provincial and national levels, there is a need for the church to embark on educating its members, especially the leadership.

\section{Multi-faith Approach to Church-State Relations}

The church can increase its strength through collaborating with other civil society organizations who are seeking to address issues of common concern. Linked to the above, partnership with faith-based organizations requires that the church cross not only denominational lines but also multi-religious ones. During the struggle against apartheid there was cooperation between Christians and people of other faiths, which was a sacrifice, sometimes going against the teaching of these faiths. This is echoed by Farid Esack (a Muslim) when he notes that:

There is a theological and historical basis for justifying a contextual approach to the Qur'an itself and the role of people in elaborating its meaning. This approach has enabled many a progressive Islamist in South Africa to engage the apartheid regime meaningfully and in solidarity with the religious other. They have done so despite the

Qur'an warning to those of faith against taking the Christians and Jews as their awliya friends/allies/supporters (1997:49).

Some of the churches (especially mainline) are members of the National Religious Leaders Forum (NRLF), which comprises representatives from most of the religious bodies in the country. This forum also interacts with government through its bi-monthly meetings. This has increased cooperation between the church and other religious groups especially when it comes to issues of common concern that they need to raise with government. However, this cooperation has been effective only at the institutional, national and agency level, not at the local congregational or mosque level. This is made difficult by the fact that from its beginning as a nation South Africa has always been a Christian country. Christians have enjoyed the benefits of belonging to a state religion, protected by the constitution over and against other faiths. As a result most South African Christians find it difficult to relate to other faiths with mutual respect and without imposing their belief systems. There is a need to build bridges across religious lines, so that the religious community can interact with the neutral-religious state with one coherent voice. For this to happen the church must be humble enough to repent for its dominance in the past, ask for forgiveness and reconcile with members of other faiths. Muslims, Hindus, Jews and adherents of African Traditional Religions need to be prepared to offer a hand of forgiveness and reconciliation to Christians for the sake of democracy and a better South Africa.

\section{Conclusion}

The essay has argued for the church's involvement in the contemporary struggles for democracy in South Africa. It has demonstrated that the church can contribute in various ways in the development of a culture of democracy in a neutral-religious state. This requires that it cooperate with government where necessary while at the same time standing firmly with the poor and marginalized. It has to take advantage of the permission given to it by the constitution for the observation of religious practices even in government institutions and the freedom of religion which is protected by law. The future of the ministry of the church in a democratic South Africa depends on how it relates to, and champions the cause of the ordinary citizens. It needs to appreciate their aspirations, while restoring their hope 
and dignity by keeping the state and its representatives accountable to basic principles of good governance and democracy (Mugambi 1995:176). As it does that, it will be responding to the words of George Washington who said that "the price to pay for democracy is eternal vigilance" (in Taylor 1988:344). The task that the church has to play in South Africa which has not yet been precedented in any African democracy is to empower citizens to pay this price if democracy is to mature in this country.

\section{BIBLIOGRAPHY}

Allen, J 2006. Rabble-Rouser for Peace: The Authorized Biography of Desmond Tutu. London: Rider Books.

Asmal, K (ed.) 2003. Nelson Mandela: From Freedom to the Future. Johannesburg: Jonathan Ball Publishers.

Balcomb, T 2004. Left, Right and Centre: Evangelicals and the Struggle for Liberation in South Africa, Journal of Theology for Southern Africa, March 2004, Number118.

Bonino, M 1983 Towards a Christian Political Ethics. London: SCM Press.

Boon, M 1996. The African Way: The power of interactive leadership. Johannesburg: Zebra.

Bua Komanisi Information Bulletin of the Central Committee of the South African Communist Part Vol 5, Issue no 1, May 2006, 24.

Chapman, A \& Spong, B 2003. Religion \& Reconciliation in South Africa. Philadelphia: Templeton Foundation Press.

Calland, R and Graham, P 2005. Democracy in the Time of Mbeki. Cape Town: IDASA.

Challenge Magazine, 13 October 1998.

Challenge Magazine, 22 June 1994.

Cloete, JJN 1983. Democracy. Prospects for South Africa. Pretoria: JL van Schaik.

Chikane, F and Alberts, L (eds.) 1991. The Road to Rustenburg: the Church Looking Forward to a New South Africa, Cape Town: Struik Christian Books.

Chikane, F 1988. No Life of My Own: An Autobiography, Johannesburg: Skottaville.

Chirwa, W 1998. Democracy Consolidation Programme. Blantyre: DCP.

Cloete, JJN 1983. Democracy. Prospects for South Africa. Pretoria: JL van Schaik.

Crawford, R 1989.Journey into Apartheid. London: Epworth Press.

De Gruchy, J 2004. The Church Struggle in South Africa. Britain: SCM Press.

De Gruchy, S 2002. "Theological Education and Social Development." Missionalia, (2002) 452.

De Klerk, 1998. FW de Klerk: The Last Trek a New Beginning. London: Macmillan.

Elphick, R \& Davenport, R 1997. Christianity in South Africa: A Political and Social Cultural History. Cape Town: David Phillip.

Esack, F 1997. Qur'an Liberation \& Pluralism: An Islamic Perspective of Interreligious Solidarity Against Oppression. Oxford: One World Publications.

Fayemi, K 2006. Imperatives of Transition in Nigeria. New Agenda. Issue 23, Third Quarter 2006, 52-57.

Hendricks, J \& Erasmus, J 2005. Religion in South Africa: The 2001 Population Census Data. Journal of Theology for Southern Africa No 121, March 2005.

Kastfelt, N 2005. Religion and African Wars London: Hurst \& Company. 
Kobia, S and Koegelenberg, R 1995. The Reconstruction and Development Programme (RDP) The role of the Church, civil society and NGOs. Cape Town: EFSA.

Kumalo, S 2005. Prophetic Christianity and Church-State relations after ten years of Democracy. Missionalia, 33:1 (April 2005) 99-110.

Longman T 2005. Churches and Social Upheavals in Rwanda and Burundi in Kastfelt, N. Religion and African Wars. London: Hurst \& Company.

Mail \& Guardian, November 3, 2006.

Mail \& Guardian August 23, 2006.

Mathebe, L 2001. Bound By Tradition. Pretoria: Unisa.

Mbeki, T 2006. Umrhabulo Weekly Newsletter of the ANC, 3 November 2006.

Mokabane, A 2006. Reflections on our Public life. Tloriso Newsletter, 24th August 2006.

Moyser, G 1991 Politics and Religion. London: Routledge.

Mugambi, JNK 1995. From liberation to Reconstruction: African Christian Theology after the Cold War. Nairobi: EAEP.

Pillay, U (ed.) 2006. South African Social Attitudes: Changing Times, Diverse Voices. Cape Town: HSRC Press.

Pityana, B \& Villa-Vicencio C, 1995. Being the Church in South Africa Today. Johannesburg: SACC.

Polley, J 1988. The Freedom Charter and the Future. Cape Town: IDASA.

Report of the Theology and Democracy Training, 9 March 2006.

Setiloane, G 1986. Introduction to African Theology. Johannesburg: Skottaville.

Shearing C and Wood, J 2005. Rethinking Citizenship \& Governance in Urban South Africa in Curry, J and Phillip, D. Limitations to Liberation after Apartheid Cape Town: David Phillip.

Smit, D 1996. Oor die kerk as 'n unieke samelewingsverband. Tydkrif vir Geesteswetenskappe 36 (1996) 2, 119-129.

Sparks, A 2006. The Mind of South Africa, Johannesburg: Jonathan Ball.

Taylor, B 1988. Parting the Waters: America in the King Years 1954-63. New York: Simon and Schuster.

Temkin, B 2003. Buthelezi: A Biography, London: Frank Cass.

Van der Ross, R 2004. African Renaissance and Democracy: Can it Work Kenilworth: Ampersand Press.

Villa-Vicencio, C 1992. A Theology of Reconstruction: Nation-Building and Human Rights Cape Town: David Phillip.

Walshe, P 1992. Prophetic Christianity and the Liberation Movement in South Africa . Pietermaritzburg: Cluster Publication.

World Bank 2002. Worldwide Governance Indicators, 2002, 11. 